\title{
Model Sistem Dinamik untuk Meramalkan Bilangan Pesakit dan Keperluan Sumber Tenaga di Zon Kuning Jabatan Kecemasan
}

(A System Dynamics Model to Predict the Number of Patients and Resources Required in Emergency Department's Yellow Zone)

\author{
NAZHATUl SAHIMA MoHd Yusoff, CHOONG-Yeun LIONG*, ABU YAZID MD NoH, \\ WAN ROSMANIRA ISMAIL \& NORAZURA AHMAD
}

\begin{abstract}
ABSTRAK
Jabatan Kecemasan Hospital Universiti Sains Malaysia (JKHUSM) telah menunjukkan perubahan yang pesat dan menghadapi transformasi drastik berhubung dengan kepentingan dalam sistem penjagaan kesihatan. Peramalan dan perancangan sumber yang munasabah perlu dilakukan bagi memenuhi permintaan pesakit yang kian bertambah. Justeru, kajian ini memfokuskan kepada Zon Kuning di JKHUSM yang memerlukan perancangan sewajarnya atas keperluan sumber yang sepatutnya disediakan pada masa kini dan akan datang untuk membantu pihak pengurusan dalam perancangan strategik jabatan serta menambah baik aliran pesakit dan perkhidmatan di zon tersebut. Pemodelan Sistem Dinamik telah dibangunkan untuk meramalkan bilangan pesakit yang akan berkunjung serta jumlah sumber yang diperlukan untuk memenuhi permintaan perkhidmatan di Zon Kuning JKHUSM pada masa sekarang (2014) dan masa hadapan bagi tempoh lima (2019) dan sepuluh tahun akan datang (2024). Hasil kajian meramalkan sumber yang diperlukan bagi memenuhi permintaan pesakit yang berkunjung di Zon Kuning pada masa sekarang adalah seramai 11 orang doktor, 12 orang jururawat dan 18 buah katil berbanding dengan sembilan orang doktor, sembilan orang jururawat dan 16 buah katil sedia ada. Seterusnya penambahan dua buah katil diramalkan untuk memenuhi keperluan pesakit bagi tempoh lima dan sepuluh tahun akan datang. Manakala tiada penambahan doktor dan jururawat diperlukan bagi memenuhi permintaan pesakit bagi tempoh lima tahun akan datang. Namun begitu dijangkakan penambahan seorang doktor dan seorang jururawat diperlukan bagi memenuhi permintaan 10 tahun akan datang. Oleh itu, peramalan penambahan sumber ini adalah sangat penting untuk menambah baik aliran pesakit di Zon Kuning JKHUSM serta membantu dalam mencapai Penunjuk Prestasi Utama jabatan ini. Hasil kajian yang diperoleh akan membantu pihak pengurusan membuat keputusan yang wajar dengan belanjawan yang telah ditetapkan demi meningkatkan kualiti perkhidmatan yang ditawarkan di samping meningkatkan tahap prestasi Zon Kuning JKHUSM.
\end{abstract}

Kata kunci: Jabatan kecemasan; penunjuk prestasi utama; peramalan; sistem dinamik; sumber tenaga; zon kuning

\section{ABSTRACT}

Emergency Department of Hospital Universiti Sains Malaysia (EDHUSM) has shown rapid changes and is facing a drastic transformation in relation to the importance of the healthcare system. Reasonable resource forecasting and planning should be done to meet the growing demands of patients. Hence, this study is focusing on the Yellow Zone in JKHUSM which requires proper planning on the needs of the resources that should be available now and in the future to assist the management in the department's strategic planning as well as to improve the patients flow and services in the zone. Systems Dynamics modeling is used to forecast the number of patients that will visit, and predict the resources required to match the demand and supply in the Yellow Zone at present (2014) and in the future for the next five (2019) and ten years (2024). The results showed that 11 doctors, 12 nurses and 18 beds are needed compared to nine doctors, nine nurses and 16 beds to cater for patients visiting the Yellow Zone at present. Furthermore, an addition of two beds is predicted to meet the patient's needs over the next five and ten years. Meanwhile, no additional doctors and nurses are required to meet the patient's demand for the next five years. However, the addition of a doctor and a nurse is needed to meet the next 10 years' demand. Therefore, forecasting of these resources is crucial to improve the patients flow in the Yellow Zone of EDHUSM and to assist in achieving the Key Performance Indicator of the department. The results of the study will help the management to make the right decision within their stipulated budget to improve the quality of services rendered and further enhance the performance of EDHUSM's Yellow Zone.

Keywords: Emergency department; forecasting; key performance indicator; resources; system dynamics; yellow zone 


\section{Pendahuluan}

Jabatan kecemasan di sesebuah hospital merupakan jabatan yang paling sibuk dalam industri perkhidmatan kesihatan bukan sahaja di Malaysia malahan di seluruh dunia (AlRefaie et al. 2014; Aminuddin et al. 2016; Ibrahim et al. 2018a; McHugh et al. 2011). Jabatan ini beroperasi 24 jam sehari sepanjang tahun tanpa cuti. Jabatan ini dianggap kritikal kerana ia menerima pesakit yang datang dalam keadaan kritikal dan separa kritikal yang berhadapan antara situasi hidup atau mati. Selain itu jabatan ini turut menerima pesakit yang datang untuk mendapatkan rawatan bagi rawatan pesakit bukan kritikal. Oleh sebab itu, jabatan kecemasan di seluruh dunia perlu berusaha untuk mengekalkan tahap perkhidmatan yang cekap dan efisien dalam mengurangkan masa menunggu pesakit sebelum mendapatkan rawatan terutamanya pada waktu sibuk dan sesak serta menangani kekangan sumber yang terhad (Norazura et al. 2012; Yusoff et al. 2018a).

Permintaan terhadap jabatan kecemasan di hospital seluruh Malaysia telah menunjukkan peningkatan yang ketara sejak akhir-akhir ini berbanding dengan jabatan lain. Menurut Aminuddin et al. (2016), statistik pesakit yang menerima rawatan di jabatan kecemasan Pusat Perubatan Universiti Malaya pada tahun 2012 telah meningkat sebanyak 3.3\% manakala di Hospital Tengku Ampuan Rahimah Klang pada tahun 2012 juga turut menunjukkan peningkatan sebanyak $5.8 \%$. Situasi ini menyebabkan berlakunya peningkatan jumlah pesakit yang hadir, seterusnya mengakibatkan kesesakan di jabatan kecemasan. Paul et al. (2010) mengatakan kesesakan di jabatan kecemasan membawa kepada kesan negatif seperti menurunkan produktiviti doktor, salah faham antara staf yang bekerja serta meningkatkan masa menunggu pesakit untuk mendapatkan rawatan. Terdapat juga pesakit yang tidak berpuas hati dan terus meninggalkan jabatan kecemasan tanpa mendapatkan rawatan (Saghafian et al. 2012). Tidak ketinggalan masalah dalam pengurusan sumber tenaga manusia juga turut berlaku seperti kekurangan doktor dan jururawat yang bertugas terutamanya pada waktu puncak adalah punca kepada isu kesesakan yang berlaku. Selain itu, kurangnya kemudahan prasarana seperti bilik dan peralatan rawatan seperti katil turut menyebabkan berlakunya kesesakan di jabatan kecemasan sekaligus menjejaskan kualiti perkhidmatan di jabatan tersebut (Norazura et al. 2012).

Terdapat tiga zon yang diperkenalkan mengikut kes di jabatan kecemasan, iaitu Zon Merah, Zon Kuning dan Zon Hijau. Zon Merah disediakan bagi pesakit yang kritikal, Zon Kuning pula bagi pesakit yang tiba dalam keadaan separa kritikal dan Zon Hijau adalah bagi pesakit bukan kritikal. Kajian ini memfokuskan kepada Zon Kuning Jabatan kecemasan Hospital Universiti Sains Malaysia (JKHUSM), Kubang Kerian, Kelantan. Jabatan ini telah ditubuhkan pada tahun 1983 dan mula beroperasi di bangunan baharu pada 25 Disember 2014. Memandangkan Hospital Universiti Sains Malaysia (HUSM) berfungsi sebagai sebuah hospital pengajar universiti serta mempunyai pelbagai kepakaran dalam bidang perubatan maka ia sering menjadi tumpuan penduduk setempat untuk mendapatkan rawatan (Hospital Universiti Sains Malaysia 2016).

Zon Kuning merupakan zon yang dikhaskan untuk merawat pesakit separa kritikal. Tempoh masa menunggu pesakit sebelum dirawat yang ditetapkan oleh Kementerian Kesihatan Malaysia (KKM) bagi Zon Kuning adalah kurang daripada 30 minit (Aminuddin et al. 2016; Ibrahim et al. 2018b). Namun begitu, pesakit Zon Kuning masih berhadapan dengan tempoh masa menunggu melebihi 30 minit berikutan daripada peningkatan pesakit yang berkunjung ke jabatan kecemasan seperti yang telah dinyatakan oleh Ibrahim et al. (2017) dalam kajian beliau. Menurut Norazura et al. (2014) dan Weng et al. (2011), masalah kekurangan sumber seperti tenaga kerja manusia dan kemudahan rawatan seperti katil adalah faktor yang menyebabkan kelewatan untuk mendapatkan rawatan ke atas pesakit di Zon Kuning akibat perlu menunggu doktor, jururawat atau katil kosong. Memandangkan pesakit Zon Kuning adalah pesakit separa kritikal maka peningkatan dalam tempoh menunggu pesakit adalah berisiko sekiranya pesakit tidak dirawat dalam tempoh masa yang ditetapkan maka ia berpotensi mendatangkan kesan yang tidak diingini ke atas pesakit yang dikelompokkan ke Zon Kuning (Aminuddin et al. 2016; Ibrahim et al. 2018b; Norazura 2014; Weng et al. 2011).

Senario yang sama turut dihadapi oleh pesakit Zon Kuning JKHUSM. Berdasarkan perbincangan bersama dengan pihak pengurusan JKHUSM, sekiranya semua katil rawatan telah penuh maka pesakit yang memerlukan pemerhatian segera di Zon Kuning JKHUSM akan ditidurkan di atas pengusung atau didudukkan di kerusi roda terlebih dahulu bagi menerima rawatan sebelum dipindahkan ke katil yang kosong. Ini jelas menunjukkan bahawa Zon Kuning JKHUSM mengalami kekurangan sumber yang agak ketara terutamanya daripada segi bilangan katil dan memerlukan langkah penambahbaikkan dengan segera.

Oleh yang demikian, bagi mendapatkan peramalan sumber yang lebih terperinci, pesakit yang dirawat di Zon Kuning JKHUSM akan dikelaskan kepada empat kategori pesakit, iaitu pesakit separa kritikal, pesakit biasa, pesakit lelah dan pesakit bayi atau kanak-kanak. Terdapat 16 buah katil rawatan yang disediakan bagi merawat keperluan pesakit di zon ini dan ia dikhususkan mengikut kategori pesakit. Dua buah katil rawatan diperuntukkan bagi kegunaan pesakit separa kritikal, iaitu pesakit yang memerlukan pemerhatian yang lebih daripada pihak doktor dan jururawat, sembilan buah bagi kegunaan pesakit biasa yang merupakan pesakit yang lebih stabil, empat buah bagi kegunaan pesakit lelah, manakala sebuah bagi kegunaan pesakit bayi atau kanak-kanak. Sekiranya katil tidak mencukupi bagi kategori tertentu maka pesakit akan ditempatkan di mana-mana katil yang kosong.

Selain itu, peningkatan populasi dan permintaan bagi perkhidmatan kesihatan turut menyumbang kepada peningkatan bilangan pesakit di jabatan kecemasan (Hong \& Ghani 2006; Norazura et al. 2012b). Justeru, hasil perbincangan bersama dengan pihak pengurusan 
JKHUSM, menyatakan bahawa peningkatan bilangan pesakit sebanyak 10\% saban tahun ke Zon Kuning JKHUSM seperti yang ditunjukkan pada Jadual 1, menjadikan zon ini turut mengalami kesesakan. Berdasarkan jadual tersebut, bilangan pesakit yang berkunjung ke Zon Kuning JKHUSM bagi tempoh empat tahun dari 2014 hingga 2017 telah meningkat daripada 18500 kepada 24703.

JADUAL 1. Bilangan pesakit yang berkunjung ke zon kuning JKHUSM

\begin{tabular}{cc}
\hline Tahun & Bilangan pesakit zon kuning \\
\hline 2014 & 18500 \\
2015 & 20356 \\
2016 & 22410 \\
2017 & 24703 \\
\hline
\end{tabular}

Sumber: Jabatan Kecemasan Hospital Universiti Sains Malaysia (2014-2017)

Sehubungan dengan itu, langkah yang efektif perlu diambil untuk mengurangkan masa menunggu pesakit untuk mendapatkan rawatan, memperbaiki mutu perkhidmatan yang diberikan, mengurangkan masalah kesesakan yang dihadapi dan seterusnya mencapai Penunjuk Prestasi Utama (KPI) jabatan yang disasarkan bagi setiap zon. Penyelidik terdahulu telah menjalankan pelbagai kajian di jabatan kecemasan dengan menggunakan pendekatan simulasi bagi memodelkan keseluruhan zon dalam jabatan kecemasan bagi menambahbaik masa menunggu pesakit dan mengenal pasti bilangan sumber yang diperlukan dalam meningkatkan kecekapan aliran pesakit di jabatan kecemasan (Aminuddin et al. 2016; Blasak et al. 2003; Chahal \& Eldabi 2008; Gunal \& Pidd 2010; Komashie \& Mousavi 2005; Rashwan et al. 2015; Uriarte et al. 2015). Kajian ini akan menggunakan pendekatan simulasi SD dalam menambahbaik aliran pesakit di Zon Kuning JKHUSM. Namun begitu, pemodelan simulasi SD yang lebih terperinci adalah kelainan yang dilakukan dalam kajian ini berbanding dengan kajian lain di Zon Kuning. Pemodelan simulasi SD bagi Zon Kuning akan dikelaskan kepada empat kategori pesakit, iaitu pesakit separa kritikal, pesakit biasa, pesakit lelah dan pesakit bayi atau kanak-kanak bagi mendapatkan peramalan sumber yang lebih terperinci bagi setiap kategori pesakit untuk tujuan penambahbaikan di Zon Kuning. Hasil yang diperoleh dapat mengenal pasti keperluan bilangan katil yang diperlukan bagi setiap kategori pesakit bagi memenuhi permintaan pesakit di Zon Kuning JKHUSM.

Terdapat beberapa kaedah yang digunakan oleh penyelidik terdahulu dalam membuat peramalan dengan menggunakan kaedah statistik seperti analisis siri masa, regresi multivariat dan regresi Poisson (Brennan et al. 2014; Rafael et al. 2016; Wu et al. 2016). Walau bagaimanapun, menurut Norazura et al. (2012a), penggunaan kaedah statistik memerlukan persamaan matematik yang lebih rumit dan sukar untuk difahami dalam menyelesaikan permasalahan yang kompleks seperti di jabatan kecemasan berbanding dengan pemodelan Sistem Dinamik (SD) yang lebih mudah untuk difahami dan dapat dilihat perkaitan antara satu unit dengan unit yang lain. Tambahan lagi, kaedah SD juga mampu untuk mereka bentuk dan membangunkan perwakilan matematik bagi membantu untuk membuat keputusan di peringkat pengurusan tertinggi serta dapat membantu dalam perancangan strategik jabatan (Norazura et al. 2012a). Selain itu, beberapa pengkaji lain turut menyokong bahawa model SD mempunyai keupayaan ramalan yang lebih tinggi, lebih tepat dan lebih sesuai berbanding dengan kaedah lain untuk menyelesaikan permasalahan bagi sistem yang kompleks seperti di jabatan kecemasan (Brailsford et al. 2010; Hassan \& Minato 2017; Norazura et al. 2014, 2013; Yusoff et al. 2018a).

Dalam kajian ini, model simulasi SD Zon Kuning akan dilarikan bagi tempoh 10 tahun bermula dari tahun 2014 sehingga 2024. Tahun 2014 ditetapkan sebagai tahun permulaan base case, kerana mengambil kira JKHUSM mula beroperasi di bangunan yang baharu serta mengguna pakai sumber yang baharu. Manakala lima tahun (2019) dan sepuluh tahun (2024) dipilih untuk meramalkan jumlah pesakit dan keperluan sumber yang diperlukan di Zon Kuning pada masa hadapan kerana mengambil kira tempoh tersebut sebagai tempoh perancangan strategik jabatan.

\section{TATAKAEDAH KAJIAN}

\section{PEMODELAN SD}

Hasil daripada kemajuan dalam teknologi komputer, perhatian terhadap SD telah meningkat kerana kaedah ini terbukti menjadi satu mekanisma yang mampu membantu pembuatan keputusan. SD telah dibangunkan oleh Jay Forrester di Massachusetts Institute of Technology pada tahun 1950-an sebagai suatu pendekatan untuk memahami sistem yang kompleks dari semasa ke semasa (Tehseen \& Amos 2015). Selain itu, SD turut menawarkan aspek kualitatif dan kuantitatif untuk meningkatkan lagi pemahaman terhadap proses dan tingkah laku sistem (Norazura et al. 2012).

Pada masa kini, kaedah SD telah digunakan secara meluas dalam pelbagai bidang untuk menyelesaikan masalah antaranya dalam bidang kesihatan, pendidikan, ekonomi, pengurusan perniagaan dan insurans (Hashimah et al. 2017). Kaedah SD adalah teknik yang sesuai untuk mengkaji masalah sistem yang kompleks. Di samping itu, kaedah SD juga memberi tumpuan kepada sistem daripada perspektif makro yang boleh digunakan untuk membuat keputusan peringkat strategik. Simulasi SD dapat dijalankan bagi memahami impak jabatan kecemasan terhadap unit-unit lain di hospital jika perubahan ingin dibuat di jabatan kecemasan (Norazura et al. 2014). Begitu juga, SD mempunyai keupayaan untuk meramalkan keadaan atau keperluan pada masa hadapan (Alasad et al. 2012; Yusoff et al. 2018a). Sebagai contoh, perubahan dalam populasi pada masa akan datang mungkin memberi kesan kepada permintaan pesakit pada masa akan datang. Selain 
itu, kaedah SD mempunyai keupayaan untuk mengambil kira faktor kuantitatif dan kualitatif yang berbeza untuk menerangkan interaksi dinamik antara faktor ini (Alasad et al. 2012; Norazura et al. 2012; Hassan \& Minato 2017). Oleh yang demikian, kajian ini menggunakan pemodelan SD untuk meramalkan permintaan pesakit dan keperluan sumber yang diperlukan di Zon Kuning JKHUSM pada masa kini dan bagi tempoh lima dan sepuluh tahun akan datang. Merujuk kepada perbincangan dengan pihak JKHUSM, peramalan pada masa hadapan adalah sebagai persediaan kepada pihak pengurusan JKHUSM untuk bersiap sedia dengan permintaan yang semakin meningkat saban tahun serta sebagai penanda aras untuk perancangan strategik jabatan. Selain itu, tempoh tersebut diambil kira dalam kajian ini kerana ia merupakan tempoh perancangan strategik jabatan. Sebelum model SD di Zon Kuning JKHUSM dibangunkan, menurut Hashimah et al. (2017) dan Sterman (2000), terdapat lima peringkat dalam proses pembangunan model simulasi SD. Oleh yang demikian, model simulasi SD di Zon Kuning JKHUSM yang dibangunkan adalah melalui lima peringkat tersebut, iaitu pengenalan masalah, perumusan hipotesis dinamik, perumusan model, pentahkikan model dan reka bentuk dasar dan evolusi.

\section{PEMBINAAN DIAGRAM GELUNG BERSEBAB}

Menurut Hashimah et al. (2017) dan Sterman (2000), Diagram Gelung Bersebab (DGB) digambarkan sebagai kesan kualitatif untuk menganalisis kelakuan sistem. Tujuan pembinaan DGB adalah untuk menunjukkan hubungan sebab dan akibat dalam SD sebelum ditukar ke model berkomputer. DGB yang bertindak sebagai hipotesis dinamik dalam pembangunan model SD mengandungi pemboleh ubah berkait dengan pautan positif $(+)$ atau negatif(-). DGB juga menerangkan kelakuan sistem dengan menunjukkan sekumpulan nod yang saling berhubung dengan anak panah dan gelung maklum balas. Anak panah kemudian menunjukkan bagaimana pemboleh ubah mempengaruhi pemboleh ubah lain. Selain itu, DGB juga dapat menggabungkan pemboleh ubah kuantitatif dan kualitatif dalam satu model SD yang dibangunkan. Pemboleh ubah kuantitatif adalah sesuatu yang dapat diukur, sementara pemboleh ubah kualitatif adalah unsur yang tidak mempunyai pengukuran secara langsung seperti motivasi dan sikap. Terdapat dua jenis gelung dalam sesebuah DGB, iaitu gelung pengukuhan (R) dan gelung keseimbangan (B). Gelung pengukuhan (R) menunjukkan jika ada perubahan pada pemboleh ubah, maka akan ada perubahan pada arah yang sama dalam pemboleh ubah yang lain. Perubahan ini boleh menyebabkan peningkatan atau penurunan. Manakala gelung keseimbangan (B) pula menunjukkan di mana perubahan itu berada di arah bertentangan, maka ia menyebabkan gelung ini akan mengimbangi kelakuannya kerana ia bertujuan untuk menggerakkan keadaan semasa ke keadaan atau tujuan yang diingini. Rajah 1 menunjukkan DGB bagi pesakit di Zon Kuning JKHUSM yang dibina dengan menggunakan perisian Vensim DSS.
Merujuk kepada Rajah 1, anak panah yang bertanda positif $(+)$ menunjukkan jika ada perubahan pada pemboleh ubah, maka akan ada perubahan pada arah yang sama dalam pemboleh ubah yang lain. Sebagai contoh, apabila kemasukan pesakit ke Zon Kuning meningkat, maka ia akan menyebabkan kepada peningkatan jumlah pesakit di Zon Kuning. Apabila berlakunya peningkatan jumlah pesakit di Zon Kuning, maka permintaan terhadap doktor, jururawat dan katil juga akan meningkat. Sebaliknya, apabila kemasukan pesakit ke Zon Kuning berkurangan, maka jumlah pesakit di zon kuning juga akan berkurangan. Manakala bagi anak panah negatif (-) pula, ia bermaksud jika peningkatan (penurunan) dalam pemboleh ubah akan menghasilkan penurunan (peningkatan) dalam pemboleh ubah yang lain. Sebagai contoh, apabila ramai pesakit yang discaj, ia akan menyebabkan jumlah pesakit di Zon Kuning berkurangan. Terdapat satu gelung pengukuhan (R1) dan dua gelung keseimbangan (B1) dan (B2) dalam DGB yang dibina. Ia menerangkan bahawa semakin meningkat kadar kemasukan maka semakin meningkat jumlah pesakit Zon Kuning. Seterusnya apabila jumlah pesakit Zon Kuning meningkat maka penetapan pesakit Zon Kuning mengikut kategori juga akan meningkat dan turut mengakibatkan peningkatan kepada jumlah pesakit yang dirawat. Apabila berlaku peningkatan jumlah pesakit yang dirawat maka semakin ramai pesakit yang akan discaj. Walau bagaimanapun, apabila semakin meningkat kadar discaj maka jumlah pesakit di Zon Kuning juga akan menurun.

\section{PEMBINAAN DIAGRAM ALIRAN STOK}

Diagram aliran stok (DAS) adalah diagram berstruktur yang menyediakan bahasa visual yang lebih baik daripada DGB. Menurut Hashimah et al. (2017), kesan kuantitatif adalah sukar untuk didedahkan menggunakan DGB terutamanya bagi sistem yang kompleks. Sebaliknya, kesan kuantitatif boleh ditemui dengan mudah dengan menggunakan DAS. Justeru, stok dan aliran diungkapkan secara persamaan dalam model SD. Jadual 2 berikut mempamerkan notasi penjenamaan untuk mewakili komponen stok dan aliran yang terkandung dalam perisian Vensim DSS.

\section{MODEL SD ZON KUNING}

Bagi mendapatkan ramalan yang lebih terperinci, model SD Zon Kuning di JKHUSM dipecahkan kepada beberapa submodel, iaitu model pesakit Zon Kuning, model pesakit biasa Zon Kuning, model pesakit separa kritikal Zon Kuning, model pesakit lelah Zon Kuning dan model pesakit bayi atau kanak-kanak Zon Kuning. Data yang diperlukan untuk membangunkan model SD Zon Kuning adalah jumlah pesakit keseluruhan zon kuning; jumlah pesakit mengikut kategori, iaitu kategori pesakit biasa, separa kritikal, lelah dan bayi atau kanak-kanak; jumlah doktor dan jururawat yang bertugas; jumlah keseluruhan katil yang disediakan serta jumlah katil yang dikhaskan bagi setiap kategori pesakit. Kesemua data, pemboleh ubah dan input yang diperlukan dalam membangunkan model 


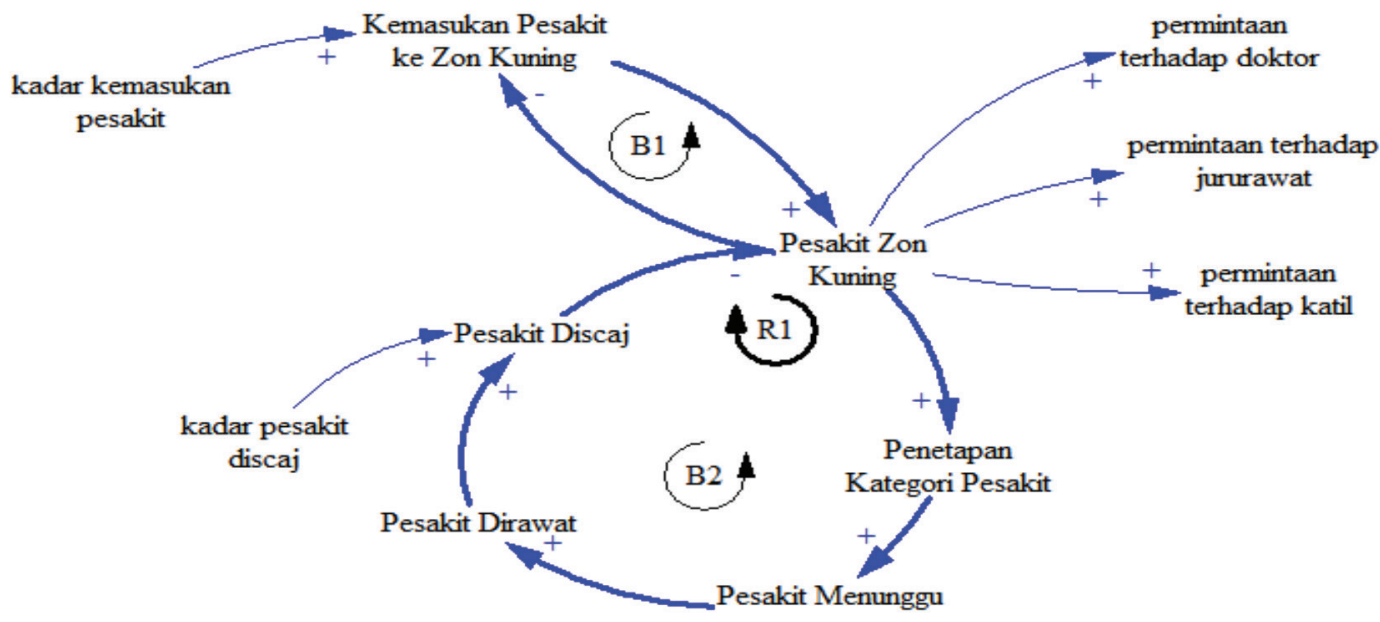

RAJAH 1. Diagram Gelung Bersebab bagi pesakit di Zon Kuning

JADUAL 2. Notasi diagram aliran dan stok

\begin{tabular}{|c|c|c|}
\hline Elemen & Huraian & Simbol \\
\hline Stok & $\begin{array}{l}\text { Pemboleh ubah yang bertambah atau berkurang } \\
\text { yang menunjukkan keadaan sesuatu sistem dari } \\
\text { semasa ke semasa }\end{array}$ & \\
\hline Aliran & $\begin{array}{l}\text { Menggambarkan aliran masuk dan aliran keluar } \\
\text { daripada stok }\end{array}$ & $\underset{\text { Alitran }}{\nabla}$ \\
\hline Injap & $\begin{array}{l}\text { Mengawal aliran masuk dan aliran keluar yang } \\
\text { mengubah keadaan stok dari semasa ke semasa }\end{array}$ & 吾 \\
\hline Penghubung & $\begin{array}{l}\text { Menggambarkan hubungan antara elemen dalam } \\
\text { sistem }\end{array}$ & \\
\hline
\end{tabular}

SD Zon Kuning diperoleh berdasarkan pemerhatian yang dilakukan serta hasil perbincangan dan cadangan daripada pihak pengurusan JKHUSM. Model ini dilarikan bermula dari tahun ia beroperasi, iaitu dari tahun 2014 hingga tahun 2024 (10 tahun) selari dengan objektif kajian ini, iaitu untuk meramalkan keperluan sumber yang diperlukan di Zon Kuning JKHUSM pada masa sekarang serta bagi tempoh lima dan sepuluh tahun akan datang kerana tempoh tersebut merupakan tempoh perancangan strategik jabatan.

\section{SUBMODEL PERAMALAN JUMLAH PESAKIT, BILANGAN} DOKTOR DAN JURURAWAT DI ZON KUNING

Submodel yang ditunjukkan dalam Rajah 2 adalah bertujuan untuk mendapatkan jumlah kemasukan tahunan pesakit ke Zon Kuning. Berdasarkan jumlah pesakit tersebut, maka peramalan bilangan doktor dan bilangan jururawat yang munasabah adalah sangat penting demi memenuhi permintaan pesakit yang kian meningkat saban tahun di Zon Kuning JKHUSM. Oleh yang demikian, Rajah 2 turut menunjukkan peramalan sumber bagi mendapatkan bilangan doktor dan bilangan jururawat yang optimum bagi memenuhi keperluan di Zon Kuning JKHUSM.

Secara matematiknya model simulasi SD boleh digambarkan sebagai satu set persamaan penting yang mewakili stok terkumpul atau aliran bersih bersepadu pada masa diskret, $t$ (Hasimah et al. 2017; Hassan \& Minato 2017; Rashwan et al. 2015; Sterman 2000). Perwakilan matematik umum bagi stok ditunjukkan pada (1).

$$
\text { Stok }(\mathrm{T})=\int_{t_{0}}^{T}(\text { aliran masuk }- \text { aliran keluar }) d t+\operatorname{Stok}\left(t_{0}\right)
$$

Submodel pesakit Zon Kuning seperti yang ditunjukkan pada Rajah 2 adalah untuk mendapatkan jumlah kemasukan tahunan pesakit ke Zon Kuning. Stok atau pemboleh ubah Pesakit Zon Kuning dipengaruhi oleh elemen pesakit Zon Kuning masuk dan elemen pesakit Zon Kuning discaj. Elemen pesakit Zon Kuning masuk pula dipengaruhi oleh elemen kadar kemasukan pesakit Zon Kuning pada setiap tahun. Manakala elemen pesakit Zon Kuning discaj pula dipengaruhi oleh kadar pesakit Zon Kuning discaj. Rumus matematik berkaitan dengan stok dan submodel Pesakit Zon Kuning yang digambarkan seperti dalam Rajah 2 ditunjukkan pada (2) hingga (4).

Jumlah Pesakit Zon Kuning $(T)=\int_{t_{0}}^{T}$ (Pesakit zon kuning masuk - Pesakit zon kuning discaj)dt + Jumlah Pesakit Zon Kuning $\left(t_{0}\right)$ 


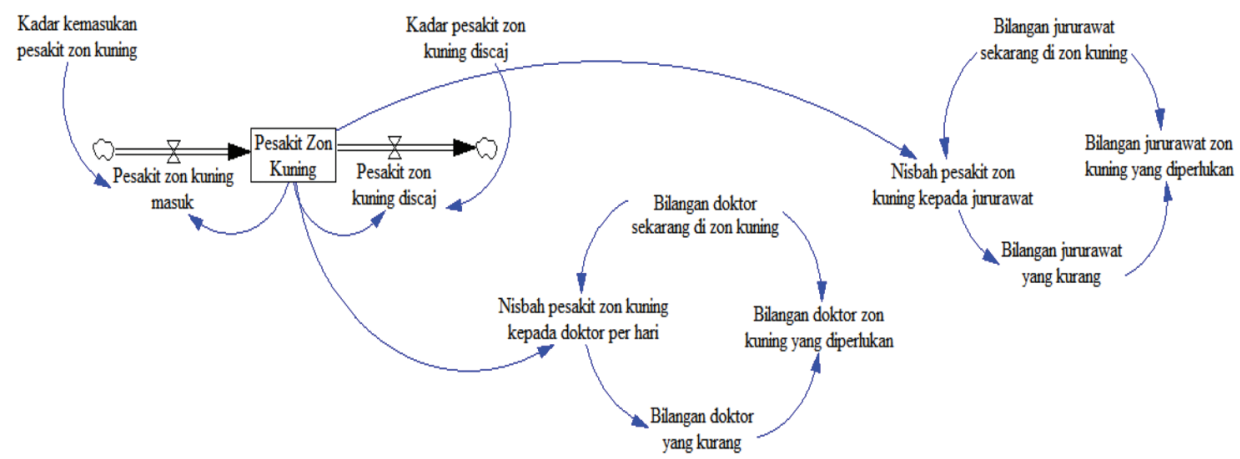

RAJAH 2. Submodel peramalan jumlah pesakit, bilangan doktor dan bilangan jururawat di Zon Kuning

\section{Pesakit zon kuning masuk $=$ Kadar kemasukan pesakit $\times$ Jumlah Pesakit Zon Kuning}

Pesakit zon kuning discaj $=$ Kadar pesakit zon kuning discaj Jumlah pesakit $\times$ Zon Kuning

Seterusnya persamaan yang terlibat bagi peramalan bilangan doktor dan jururawat yang diperlukan di Zon Kuning JKHUSM pula dinyatakan pada (5) hingga (10).

$$
\text { Bilangan doktor sekarang di zon kuning }=9
$$

Nisbah pesakit zon kuning kepada doktor per hari $=($ Jumlah pesakit zon kuning $) /($ Bilangan doktor sekarang di zon kuning $\times 365$ )

Bilangan doktor zon kuning $=($ Bilangan doktor yang kurang di zon kuning $)+($ Bilangan doktor sekarang di zon kuning)

Bilangan jururawat sekarang di zon kuning $=9$

Nisbah pesakit zon kuning kepada jururawat per hari $=($ Jumlah pesakit zon kuning $) /($ Bilangan jururawat sekarang di zon kuning $\times 365$ )

Bilangan jururawat zon kuning = Bilangan jururawat yang kurang di zon kuning $)+($ Bilangan jururawat sekarang di zon kuning)

Merujuk kepada Rajah 3 dan 4 dan persamaan (5) hingga (10), pemboleh ubah bilangan doktor dan bilangan jururawat yang kurang di Zon Kuning adalah merupakan elemen jadual carian nilai yang mempengaruhi pemboleh ubah bilangan doktor dan bilangan jururawat yang diperlukan di Zon Kuning. Menurut Hashimah et al. (2017) dan Sterman (2000), jadual carian nilai biasanya digunakan dalam pemodelan SD yang bertindak sebagai perantara bagi mewakili hubungan tak linear antara dua pemboleh ubah. Pada asasnya, jadual carian digunakan untuk menggambarkan bagaimana input yang berbeza akan menghasilkan output yang berbeza kepada pemboleh ubah seterusnya. Dengan menggunakan fungsi jadual carian nilai, penyelidik dapat mengawal bentuk, cerun dan titik tepu pada graf untuk mewakili hubungan tak linear dengan tepat antara dua pemboleh ubah. Sebagai contoh, bagi mendapatkan bilangan doktor di Zon Kuning, jumlah pesakit di Zon Kuning dan bilangan doktor sekarang di Zon Kuning dan nisbah antara dua pemboleh ubah tersebut akan mempengaruhi bilangan doktor yang kurang di Zon Kuning seperti yang ditunjukkan pada Rajah 3. Seterusnya, bilangan doktor yang kurang di Zon Kuning dan bilangan doktor sekarang di Zon Kuning akan mempengaruhi bilangan doktor di Zon Kuning.

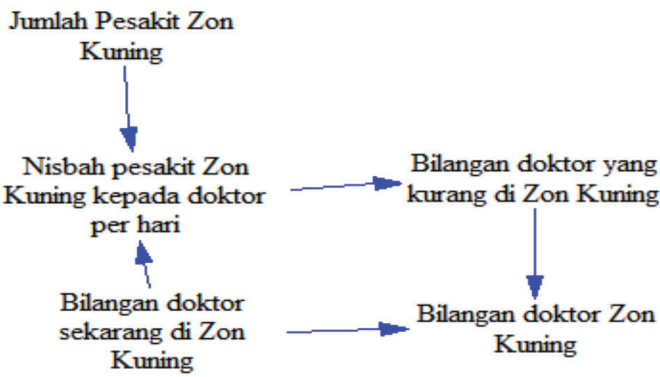

RAJAH 3. Pemboleh ubah yang terlibat bagi jadual carian nilai bilangan doktor di Zon Kuning

Menurut Hashimah et al. (2017), nilai input dan output pada jadual carian nilai hanyalah andaian oleh penyelidik dan nilai ini boleh diubah atau ditambah baik berdasarkan perbincangan yang dijalankan bersama dengan pakar agar bersesuian dengan dapatan yang ingin diperoleh bagi pemboleh ubah yang dikaji. Untuk membangunkan jadual carian nilai, kami menggunakan fungsi yang terdapat dalam perisian Vensim DSS. Rajah 4 menggambarkan jadual carian nilai bagi pemboleh ubah bilangan doktor yang kurang di Zon Kuning.

Jadual carian nilai seperti yang ditunjukkan pada Rajah 4, menggambarkan output daripada 'nisbah pesakit Zon Kuning kepada doktor per hari' yang mempengaruhi output bagi pemboleh ubah 'bilangan doktor yang diperlukan di Zon Kuning'. Dengan mengandaikan bahawa nisbah pesakit kepada doktor per hari adalah bersamaan dengan tiga orang, maka bilangan doktor yang kurang dan 


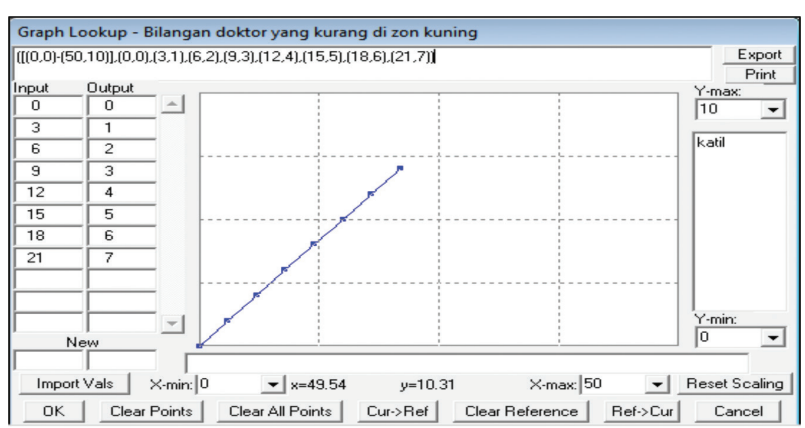

RAJAH 4. Graf jadual carian nilai bagi bilangan doktor yang diperlukan di Zon Kuning JKHUSM

sepatutnya ditambah adalah seorang. Bilangan doktor yang kurang di Zon Kuning adalah berkadar terus dengan nisbah pesakit Zon Kuning kepada doktor per hari. Semakin tinggi nisbah pesakit kepada doktor, maka semakin tinggi bilangan doktor yang kurang dan perlu ditambah di Zon Kuning.

\section{SUBMODEL PERAMALAN KATIL BAGI KATEGORI PESAKIT DI ZON KUNING}

Bagi mendapatkan keputusan yang lebih terperinci berkaitan jumlah katil yang diperlukan bagi memenuhi keperluan dan permintaan bagi setiap kategori pesakit di Zon Kuning, sebanyak empat submodel yang mewakili empat kategori pesakit di Zon Kuning telah dibangunkan. Submodel bagi kategori pesakit biasa, separa kritikal, lelah dan bayi atau kanak-kanak di Zon Kuning telah dimodelkan bagi mendapatkan ramalan keperluan katil bagi memenuhi permintaan dan keperluan pesakit pada masa sekarang dan masa hadapan bagi tempoh lima dan sepuluh tahun akan datang yang merupakan tempoh perancangan strategik jabatan. Bagi menerangkan bagaimana submodel ini dibentuk, satu contoh berkaitan penggunaan bilangan katil yang diperlukan bagi pesakit Zon Kuning telah diambil untuk penerangan.

Berdasarkan Rajah 5, stok jumlah pesakit biasa Zon Kuning yang dirawat dipengaruhi oleh pemboleh ubah pesakit biasa Zon Kuning menunggu dan pemboleh ubah pesakit biasa Zon Kuning discaj. Pemboleh ubah pesakit biasa Zon Kuning menunggu pula dipengaruhi oleh pemboleh ubah peratus penetapan pesakit Zon Kuning yang dikategorikan sebagai pesakit biasa dari jumlah keseluruhan pesakit Zon Kuning. Manakala pemboleh ubah pesakit biasa Zon Kuning discaj pula dipengaruhi oleh kadar pesakit biasa Zon Kuning discaj. Pesakit discaj dalam kajian ini merujuk kepada pesakit yang keluar daripada Zon Kuning sama ada pesakit pulang ke rumah, ke zon merah, ke wad sementara atau ke wad. Namun begitu kajian ini tidak mengambil kira proses selepas pesakit discaj daripada Zon Kuning. Rumus matematik yang terlibat bagi mendapatkan peramalan jumlah pesakit biasa yang akan dirawat (stok) dan bilangan katil yang diperlukan oleh pesakit biasa Zon Kuning pada masa kini dan masa hadapan ditunjukkan dalam persamaan (11) hingga (15).

$$
\begin{aligned}
& \text { Jumlah pesakit biasa Zon Kuning dirawat }(T)= \\
& \int_{t_{0}}^{T}(\text { Pesakit biasa zon kuning menunggu }- \text { Pesakit } \\
& \text { biasa zon kuning discaj)dt }+ \text { Jumlah pesakit biasa } \\
& \text { zon kuning dirawat }\left(t_{0}\right)
\end{aligned}
$$$$
\text { Bilangan katil pesakit sekarang di zon kuning }=9
$$

$$
\begin{aligned}
& \text { Nisbah pesakit biasa zon kuning kepada katil per } \\
& \text { hari }=(\text { Jumlah pesakit biasa zon kuning dirawat }) / \\
& (\text { Bilangan katil pesakit biasa sekarang di zon } \\
& \text { kuning } \times 365) \\
& \text { Bilangan katil pesakit biasa yang kurang di } \\
& \text { zon kuning = WITH LOOKUP (Nisbah pesakit } \\
& \text { biasa zon kuning kepada katil per hari, }([(0,0)- \\
& (60,60)],(0,0),(5,1),(10,2),(15,3),(20,4),(25,5), \\
& (30,6),(35,7),(40,8),(45,9),(50,10))
\end{aligned}
$$

$$
\begin{aligned}
& \text { Bilangan katil pesakit biasa }=(\text { Bilangan katil } \\
& \text { pesakit biasa yang kurang di zon kuning) })+ \\
& \text { (Bilangan katil pesakit biasa sekarang di zon } \\
& \text { kuning) }
\end{aligned}
$$

Bagi mendapatkan peramalan jumlah katil yang diperlukan bagi memenuhi permintaan pesakit biasa di Zon Kuning JKHUSM, jumlah pesakit biasa Zon Kuning akan dipengaruhi oleh pemboleh ubah bilangan katil pesakit sekarang di Zon Kuning dan nisbah pesakit biasa Zon Kuning kepada katil per hari. Seterusnya nisbah antara dua pemboleh ubah tersebut akan mempengaruhi bilangan katil pesakit biasa yang kurang di Zon Kuning. Akhir sekali, bilangan katil pesakit biasa akan ditentukan oleh output yang diperoleh daripada pemboleh ubah bilangan katil pesakit biasa yang kurang dan bilangan katil pesakit

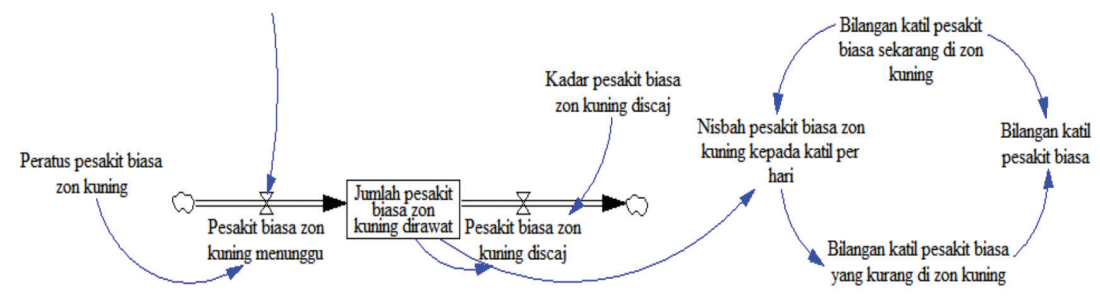

RAJAH 5. Submodel pesakit biasa di Zon Kuning 


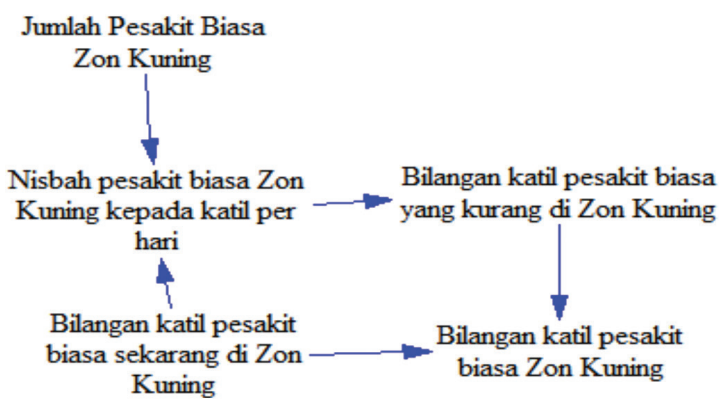

RAJAH 6. Pemboleh ubah yang terlibat bagi jadual carian nilai bilangan katil pesakit biasa Zon Kuning

biasa sekarang di Zon Kuning seperti yang ditunjukkan pada Rajah 6.

Seterusnya, jadual carian nilai seperti yang ditunjukkan pada Rajah 7, menggambarkan output daripada 'nisbah pesakit biasa Zon Kuning kepada katil per hari' yang mempengaruhi output bagi pemboleh ubah 'bilangan katil pesakit biasa yang kurang dan diperlukan di Zon Kuning'. Dengan mengandaikan bahawa sekiranya terdapat penambahan lima orang pesakit biasa di Zon Kuning maka bilangan katil yang kurang dan sepatutnya ditambah adalah sebuah katil. Bilangan katil pesakit biasa yang kurang dan diperlukan di Zon Kuning adalah berkadar terus dengan nisbah pesakit biasa Zon Kuning kepada katil per hari. Semakin tinggi nisbah pesakit biasa kepada katil, maka semakin tinggi bilangan katil yang kurang dan diperlukan di Zon Kuning.

\section{PENGESAHAN MODEL}

Setelah model SD selesai dibangunkan, ia perlu melalui proses pengesahan sebelum ia boleh digunakan. Menurut Hashimah et al. (2017), terdapat dua jenis teknik pengesahan yang boleh digunakan bagi membina keyakinan pengguna terhadap model yang dibangunkan dalam menguji kesahihan dan keberkesanan model tersebut. Dua jenis pengesahan tersebut adalah pengesahan tingkah laku dan pengesahan struktur. Justeru, bagi melaksanakan proses pengesahan tingkah laku, sesetengah pemboleh ubah dalam model SD boleh disahkan menggunakan perbandingan antara data sebenar dengan keputusan simulasi yang diperoleh. Kaedah perbandingan ini lebih dipercayai selain menggunakan kaedah pengesahan daripada pandangan pakar. Kaedah ini juga menentukan bahawa persamaan yang dimasukkan serta struktur model SD yang dibangunkan adalah betul.

Dalam kajian ini, perbandingan antara data asal dan keputusan SD yang dihasilkan bagi jumlah pesakit di Zon Kuning dari tahun 2014 hingga 2017 seperti yang ditunjukkan dalam Jadual 3 turut dijalankan untuk melihat persamaan yang wujud. Menurut Kelton (2015), perbezaan antara data sebenar dan output simulasi mestilah kurang daripada 10\% dengan menggunakan rumus (16). Berdasarkan jadual, dapat dibuat kesimpulan bahawa model SD yang dibangunkan adalah betul kerana perbezaannya kurang daripada $10 \%$.

$$
\text { Perbezaan }(\%)=\frac{\text { Data Sebenar-Keputusan Simulasi }}{\text { Data Sebenar }} \times 100 \%
$$

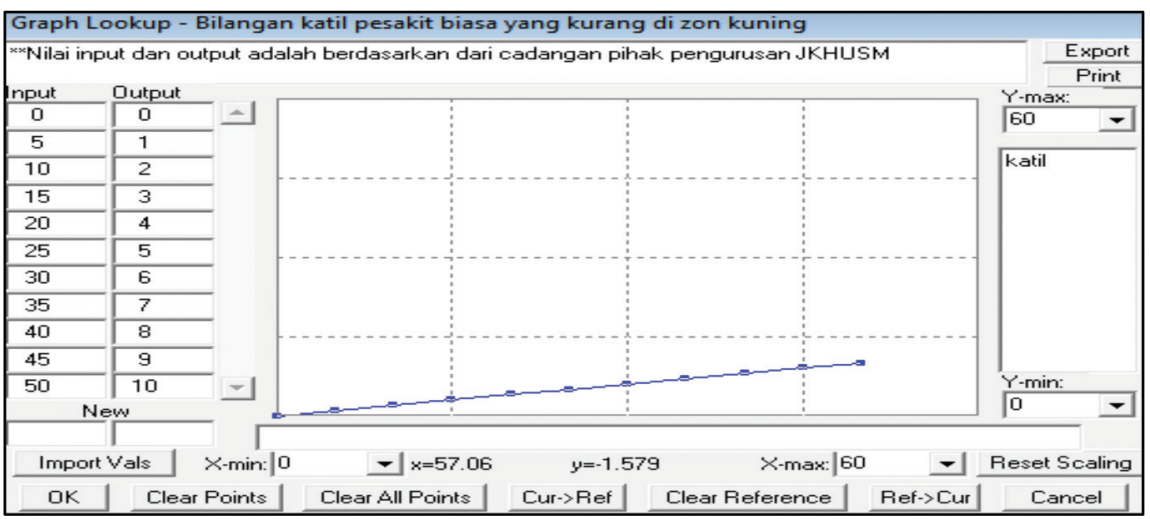

RAJAH 7. Paparan graf nilai input dan output jadual carian nilai bagi bilangan katil pesakit biasa yang diperlukan di Zon Kuning JKHUSM

JADUAL 3. Perbandingan antara data sebenar dengan keputusan SD bagi jumlah pesakit di Zon Kuning

\begin{tabular}{cccc}
\hline Tahun & $\begin{array}{c}\text { Data } \\
\text { Sebenar }\end{array}$ & $\begin{array}{c}\text { Keputusan } \\
\text { SD }\end{array}$ & $\begin{array}{c}\text { Perbezaan } \\
(\%)\end{array}$ \\
\hline 2014 & 18600 & 18600 & 0 \\
2015 & 20356 & 20350 & 0.03 \\
2016 & 22410 & 22385 & 0.11 \\
2017 & 24703 & 24623 & 0.32 \\
\hline
\end{tabular}


Manakala bagi pengesahan stuktur pula, model SD pesakit Zon Kuning yang dibangunkan telah dibentangkan dan disemak oleh Ketua JKHUSM untuk mengesahkan bahawa model tersebut mewakili aktiviti dan aliran yang betul di Zon Kuning JKHUSM. Selain itu, ujian syarat ekstrim turut dipilih dalam kajian ini. Antara sebab ujian ini berkesan untuk menilai kesahihan struktur adalah kerana ia adalah satu daripada ujian yang kuat untuk menemui kelemahan dalam struktur model. Menurut Hashimah et al. (2017) dan Sterman (2000), nilai yang paling kecil dan yang paling besar akan digunakan dalam ujian syarat ekstrim bagi menilai kesahihan struktur model yang dibangunkan. Sebagai contoh, Rajah 8 dan 9 menunjukkan perbandingan kedua-dua nilai tersebut berbanding dengan peratus kemasukan pesakit yang asal bagi pesakit biasa, iaitu 0.7. Peratus kemasukan pesakit asal yang dimasukkan dalam model SD yang dibangunkan ini diperoleh hasil perbincangan dan data yang diperoleh daripada pihak pengurusan JKHUSM.

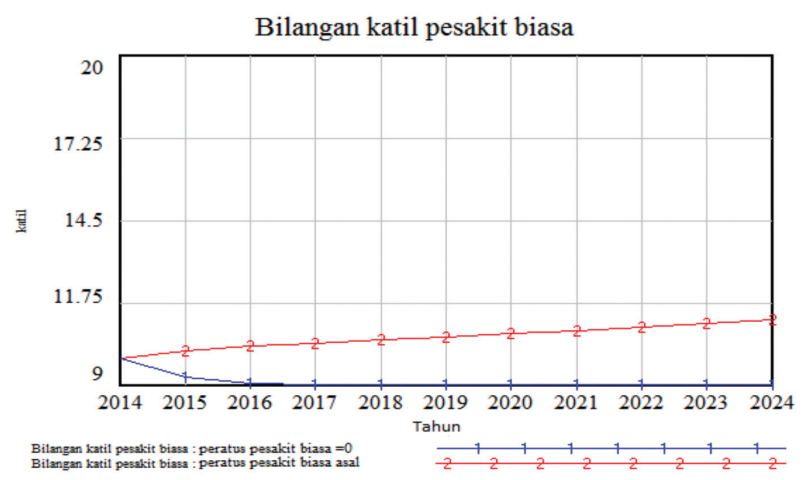

RAJAH 8. Perbandingan graf bagi peratus kemasukan pesakit biasa nilai 0 dengan peratus kemasukan pesakit biasa asal

Berdasarkan Rajah 8, perbandingan antara peratus kemasukan pesakit biasa yang diumpuk pada nilai 0 dengan peratus kemasukan pesakit biasa yang asal, iaitu 0.79 menunjukkan apabila tiada pesakit biasa yang ditetapkan sebagai pesakit biasa Zon Kuning, maka permintaan terhadap bilangan katil yang diperlukan bagi pesakit biasa akan berkurangan sehingga kembali kepada bilangan asal katil biasa yang disediakan di Zon Kuning pada masa sekarang, iaitu sejumlah 9 buah. Manakala apabila peratus pesakit biasa diumpuk kepada nilai 0.9 yang bermaksud pesakit yang ditetapkan sebagai pesakit biasa adalah lebih tinggi daripada peratus asal, iaitu 0.79, maka permintaan terhadap katil yang diperlukan bagi pesakit biasa meningkat dan lebih tinggi berbanding dengan keadaan asal seperti yang ditunjukkan dalam Rajah 9. Oleh itu, setelah menjalankan ujian syarat ekstrim dengan kadar nilai input yang ekstrim, model SD yang dibangunkan ini adalah sahih dan boleh diterima.

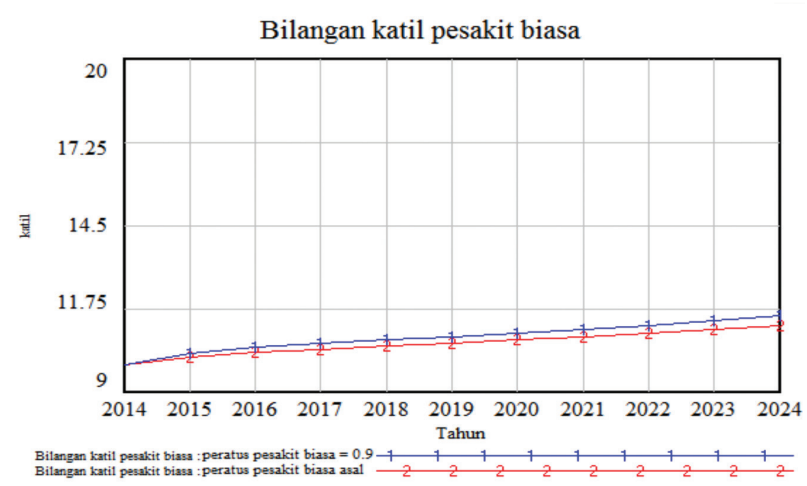

RAJAH 9. Perbandingan graf bagi peratus pesakit biasa nilai 0.9 dengan peratus pesakit biasa asal

\section{HASIL DAN PERBINCANGAN}

Ekoran daripada peningkatan bilangan pesakit sebanyak $10 \%$ saban tahun ke Zon Kuning JKHUSM, maka keperluan sumber yang disediakan pada masa sekarang adalah tidak mencukupi berdasarkan keputusan yang dihasilkan oleh model SD. Justeru, ia merupakan faktor utama yang menyumbang kepada masalah ketidakcapaian KPI di Zon Kuning JKHUSM.

Oleh yang demikian, penambahan sumber adalah sangat penting untuk meningkatkan tahap kecekapan aliran pesakit di Zon Kuning JKHUSM serta membantu untuk mencapai KPI jabatan. Jadual 4 menunjukkan dengan jelas keperluan sumber yang diperlukan seperti bilangan doktor, bilangan jururawat, jumlah katil mengikut kategori pesakit yang diramalkan oleh model SD bagi memenuhi permintaan pesakit yang berkunjung ke Zon Kuning JKHUSM pada masa sekarang serta bagi tempoh lima dan sepuluh tahun akan datang.

Hasil kajian menunjukkan jumlah doktor yang munasabah diperlukan bertugas di Zon Kuning JKHUSM pada masa sekarang adalah seramai 11 orang berbanding dengan sembilan orang sehari manakala jumlah jururawat pula adalah seramai 12 orang berbanding dengan sembilan orang sehari. Berdasarkan keputusan model SD yang dibangunkan, penambahan sebuah katil hanya diperlukan bagi kategori katil pesakit biasa dan katil pesakit lelah bagi menjadikan jumlah katil yang diperlukan di Zon Kuning adalah sebanyak 18 buah katil berbanding dengan 16 buah katil sedia ada bagi memenuhi permintaan pesakit yang berkunjung ke Zon Kuning JKHUSM pada masa sekarang (2014).

Seandainya penambahan sumber dilakukan pada masa sekarang maka penambahan dua buah katil diramalkan bagi memenuhi keperluan di Zon Kuning JKHUSM bagi tempoh lima dan sepuluh tahun akan datang. Sebuah katil bagi pesakit biasa dan sebuah katil bagi pesakit separa kritikal diramalkan perlu ditambah bagi memenuhi permintaan pesakit bagi tempoh lima tahun akan datang manakala penambahan sebuah katil bagi pesakit lelah dan sebuah katil bagi pesakit bayi atau kanak-kanak diperlukan bagi tempoh sepuluh tahun akan datang. Seterusnya 
JADUAL 4. Perbandingan antara data sebenar dan keputusan simulasi bagi jumlah pesakit dan sumber yang diperlukan di Zon Kuning JKHUSM pada masa sekarang dan bagi tempoh lima dan sepuluh tahun akan datang

\begin{tabular}{|c|c|c|c|c|}
\hline Sumber & $\begin{array}{l}\text { Data sebenar } \\
\qquad(2014)\end{array}$ & $\begin{array}{c}\text { Masa sekarang } \\
\text { (Keputusan SD) } \\
(2014)\end{array}$ & $\begin{array}{c}5 \text { tahun akan datang } \\
\text { (Keputusan SD) } \\
(2019)\end{array}$ & $\begin{array}{c}10 \text { tahun akan datang } \\
\text { (Keputusan SD) } \\
(2024)\end{array}$ \\
\hline Jumlah pesakit di Zon Kuning & 18500 & 18500 & 28794 & 47984 \\
\hline Jumlah doktor & 9 & 11 & 11 & 12 \\
\hline Jumlah jururawat & 9 & 12 & 12 & 13 \\
\hline Bilangan katil pesakit biasa & 9 & 10 & 11 & 11 \\
\hline Bilangan katil pesakit separa kritikal & 2 & 2 & 3 & 3 \\
\hline Bilangan katil pesakit lelah & 4 & 5 & 5 & 6 \\
\hline Bilangan katil pesakit bayi & 1 & 1 & 1 & 2 \\
\hline $\begin{array}{l}\text { Jumlah keseluruhan katil yang diperlukan } \\
\text { di Zon Kuning }\end{array}$ & 16 & 18 & 20 & 22 \\
\hline
\end{tabular}

tiada penambahan doktor dan jururawat diperlukan bagi memenuhi permintaan pesakit bagi tempoh lima tahun akan datang. Bagaimanapun penambahan seorang doktor dan seorang jururawat adalah diperlukan bagi memenuhi permintaan 10 tahun akan datang di Zon Kuning JKHUSM. Berdasarkan keputusan yang dihasilkan, ia jelas menunjukkan akan berlakunya peningkatan jumlah pesakit yang berkunjung ke zon kuning bagi tempoh lima dan sepuluh tahun akan datang dan ia secara langsung menyokong penyataan yang dinyatakan oleh Aminuddin et al. (2016) bahawa permintaan terhadap jabatan kecemasan di hospital seluruh Malaysia telah menunjukkan peningkatan yang ketara sejak akhir-akhir ini berbanding dengan jabatan lain. Justeru, berdasarkan hasil yang diperoleh, ia jelas menunjukkan bahawa jabatan kecemasan amnya dan Zon Kuning khusunya mengalami kekurangan sumber yang agak ketara terutamanya daripada segi bilangan doktor, jururawat dan katil serta memerlukan langkah penambahbaikkan dengan segera. Secara tidak langsung, ia bertepatan dengan hasil yang diperoleh oleh Mohd et al. (2016) dalam kajian beliau yang menyatakan perlu penambahan seramai empat orang doktor bagi menambahbaik aliran pesakit dan mengurangkan masa menunggu pesakit di Zon Kuning Pusat Perubatan Universiti Malaya (PPUM). Selain itu, hasil kajian ini juga turut menyokong hujah Aminuddin et al. (2016), Norazura et al. (2014, 2013), Yusoff et al. (2018b, 2017) bahawa perlunya penambahan bilangan sumber seperti bilangan doktor, jururawat dan katil bagi menambahbaik operasi perkhidmatan dan aliran pesakit di jabatan kecemasan. Sebarang penambahbaikan yang dilakukan akan mendorong kepada pengurangan tempoh masa menunggu pesakit yang lama, kesesakan dan ketidakpuasan pesakit terhadap perkhidmatan di hospital (Azaiez \& Al-Sharif 2005; Jeenanunta et al. 2013; Yusoff et al. 2018b, 2017). Justeru, peramalan sumber yang dihasilkan oleh model simulasi SD Zon Kuning yang dibangunkan mampu mendapatkan hasil bilangan sumber yang diperlukan bagi memenuhi permintaan pesakit yang berkunjung pada masa kini dan akan datang.

\section{KESIMPULAN}

Makalah ini membentangkan hasil kajian daripada model SD di Zon Kuning JKHUSM yang telah dibangunkan untuk meramalkan bilangan pesakit yang berkunjung dan jumlah sumber seperti bilangan doktor, jururawat dan katil yang diperlukan di Zon Kuning JKHUSM pada masa sekarang serta bagi tempoh lima dan sepuluh tahun akan datang. Berdasarkan keputusan SD yang diperoleh, jelas menunjukkan bahawa sumber sedia ada pada masa sekarang adalah tidak mencukupi bagi memenuhi keperluan pesakit di Zon Kuning JKHUSM. Perkara ini mengakibatkan kegagalan untuk mencapai KPI jabatan tersebut, iaitu pesakit perlu dirawat dalam tempoh $30 \mathrm{~min}$ dari masa ketibaan. Selain itu, keputusan SD yang diperoleh turut memberikan gambaran dan maklumat yang terperinci berkaitan dengan kategori katil yang perlu kepada penambahan. Hasil daripada kajian ini juga dapat memberi impak yang besar kepada pihak pengurusan kerana ia boleh dijadikan sebagai garis panduan dan penanda aras dalam membantu dan membimbing pihak pengurusan Zon Kuning JKHUSM untuk perancangan strategik jabatan pada masa sekarang (2014) dan pada masa hadapan bagi tempoh lima (2019) dan sepuluh tahun akan datang (2024). Di samping itu, ia adalah sebagai persediaan jabatan ke arah memenuhi peningkatan bilangan pesakit tahunan sebanyak $10 \%$ serta merancang sumber yang bersesuaian untuk menampung permintaan pada masa sekarang serta bagi tempoh lima dan sepuluh tahun akan datang. Melalui hasil kajian ini juga ia mampu membantu pihak pengurusan dalam merancang belanjawan tahunan yang diperuntukkan dalam mengambil kira penambahan sumber yang perlu dilakukan bagi melancarkan sistem aliran pesakit serta meningkatkan kualiti dan tahap kecekapan di Zon Kuning JKHUSM.

\section{PENGHARGAAN}

Penulis mengucapkan berbanyak-banyak terima kasih kepada Jabatan Kecemasan Hospital Universiti Sains Malaysia (HUSM) kerana memberi kebenaran untuk 
menjalankan kajian ini. Penulis juga ingin merakamkan berbanyak-banyak terima kasih kepada para penilai atas komen dan cadangan yang membina.

\section{RUJUKAN}

Alasad, R., Motawa, I. \& Ogunlana, S. 2012. A system dynamicbased method for demand forecasting in infrastructure projects-A case of PPP projects. Proceeding of 28th Annual ARCOM Conference. hlm. 327-336.

Al-Refaie, A., Fouad, R.H., Li, M. \& Shurrab, M. 2014. Applying simulation and DEA to improve performance of emergency department in a Jordanian hospital. Simulation Modelling Practice and Theory 41: 59-72.

Aminuddin, W.M.W.M., Ismail, W.R. \& Husyairi, H. 2016. Estimating emergency department maximum capacity using simulation and data envelopment analysis. Indian Journal of Sciences \& Technology 9(28): 1-10.

Azaiez, M.N. \& Al-Sharif, S. 2005. A 0-1 goal programming model for nurse scheduling. Computers \& Operations Research 32: 491-507.

Blasak, E.R., Starks, W.D., Armel, S.W. \& Hayduk, C. 2003. The use of simulation to evaluate hospital operations between the emergency department and a medical telemetry unit. Proceeding of 2003 Winter Simulation Conference. hlm. 1887-1893.

Brailsford, S.C., Desai, S.M. \& Viana, J. 2010. Towards the holygrail: Combining system dynamics and discrete-event simulation in healthcare. Proceeding of 2010 Winter Simulation Conference. hlm. 2293-2303.

Brennan, J.J., Chan, T.C., Hsia, R.Y., Vike, G.M., Killeen, J.P. \& Castillo, E.M. 2014. Predicting frequent use of emergency department resources. An International Journal of Annals of Emergency Medicine 64: S118-S119.

Chahal, K. \& Eldabi, T. 2008. Applicability of hybrid simulation to different models of governance in UK healthcare. Proceeding of 2008 Winter Simulation Conference. hlm. 1469-1477.

Gunal, M.M. \& Pidd, M. 2010. Discrete event simulation for performance modelling in healthcare: A review of the literature. Journal of Simulation 4(1): 42-51.

Hasimah, S., Jafri, Z., Norazura, A., Norhaslinda, Z.A. \& Nurul, N.H. 2017. Introduction to System Dynamics Modelling and Vensim Software. Serdang: UPM Press.

Hassan, F.A. \& Minato, N. 2017. A system dynamics analysis of Malaysian healthcare resources. International Journal of Japan Association for Management Systems 9(1): 61-69.

Hong, N.C. \& Ghani, N.A. 2006. A model for predicting average ambulance service travel times in Penang Island. Proceeding of the 2nd IMT-GT Regional Conference on Mathematics, Statistics and Applications. University Sains Malaysia.

Hospital Universiti Sains Malaysia. 2016. Sejarah Hospital USM. http://h.usm.my/v3/index.php/perkhidmatan. Diakses pada 25 Oktober 2017.

Ibrahim, I.M., Liong, C.Y., Bakar, S.A. \& Ahmad, N. 2018a. Estimating optimal resource capacities in emergency department. Indian Journal of Public Health Research \& Development 9(11): 1559-1565.

Ibrahim, I.M., Liong, C.Y., Bakar, S.A. \& Ahmad, N. 2018b. Performance improvement of the yellow zone in emergency department using discrete event simulation approach. International Journal of Engineering \& Technology 7(4): 102-105.
Ibrahim, I.M., Liong, C.Y., Bakar, S.A., Ahmad, N. \& Najmuddin, A.F. 2017. Minimizing patient waiting time in emergency department of public hospital using simulation optimization approach. The 4th International Conference on Mathematical Sciences, AIP Conference Proceedings. 1830: 1-8.

Jeenanunta, C., Ayudhya, S.I.N., Doungraksa, P., Sereewattanapong, C., Pongtanupattana, A. \& Nuchjarin, I. 2013. Resource analysis in emergency department using simulation-based framework. The 4th International Conference on Engineering Project and Production Management. hlm. 1073-1083.

Kelton, W.D., Sadowski, R.P. \& Zupick, N.B. 2015. Simulation with ARENA. 6th ed. Singapore: McGraw-Hill Education.

Komashie, A. \& Mousavi, A. 2005. Modeling emergency departments using discrete event simulation techniques. Proceedings of 2005 Winter Simulation Conference. hlm. 2681-2685.

McHugh, M., Van Dyke, K., McClelland, M. \& Moss, D. 2011. Improving Patient Flow and Reducing Emergency Department Crowding: A Guide for Hospitals. AHRQ Publication.

Mohd, R.Z., Muthukkaruppan, I., Kassim. \& Rashidi, A. 2016. Estimating the right allocation of doctors in emergency department. Proceedings of 2016 Management International Conference (KMICe). hlm. 446-452.

Norazura, A., Noraida, A.G., Anton, A.K. \& Razman, M.T. 2014. Managing resource capacity using hybrid simulation. International Conference on Quantitative Sciences and Its Applications. hlm. 504-511.

Norazura, A., Noraida, A.G., Anton, A.K. \& Razman, M.T. 2013. Simulating the impact of an increase in patient volume on a government emergency department in Malaysia. International Proceedings of Economics Development and Research (IPEDR). hlm. 78-82.

Norazura, A., Noraida, A.G., Anton, A.K. \& Razman, M.T. 2012a. Emergency department problems: A call for hybrid simulation. Proceedings of the World Congress on Engineering Vol III.

Norazura, A., Noraida, A.G., Anton, A.K. \& Razman, M.T. 2012b. Evaluating emergency department resource capacity using simulation. Modern Applied Science 6(11): 9-19.

Paul, S.A., Reddy, M.C. \& DeFlitch, C.J. 2010. A systematic review of simulation studies investigating emergency department overcrowding. Simulation 86(8-9): 559-571.

Rashwan, W., Abo-Hamad, W. \& Arisha, A. 2015. A system dynamics view of acute bed blockage problem in Irish healthcare system. European Journal of Operational Research 247(1): 276-293.

Rafael, C., Flavio, S.F., Filipe, R.L., Jeruza, N., Ricardo, S.K. \& Beatriz, D.S. 2016. Forecasting daily volume and acuity of patients in the emergency department. Computational and Mathematical Methods in Medicine 2016: 3863268.

Saghafian, S., Hopp, W.J., Van Oyen, M.P., Desmond, J.S. \& Kronick, S.L. 2012. Patient streaming as a mechanism for improving responsiveness in emergency departments. Operation Research 60(5): 1080-1097.

Sterman, J. 2000. Business Dynamics: System Thinking and Modelling for a Complex World. Boston: McGraw-Hill.

Tehseen, A. \& Amos, H.C.N. 2015. Strategy evaluation using system dynamics and multi-objective optimization for an internal supply chain. Proceedings of the 2015 Winter Simulation Conference. hlm. 2033-2044. 
Uriarte, A.G., Zuniga, E.R., Moris, M.U. \& Ng, A.H.C. 2015. System design and improvement of an emergency department using simulation-based multi-objective optimization. Journal of Physics 1: 1-11.

Weng, S.J., Tsai, L.M., Wang, C.Y., Chang, C.Y. \& Gotcher, D. 2011. Using simulation and data envelopment analysis in optimal healthcare efficiency allocations. Proceeding of 2011 Winter Simulation Conference, Indian Journal of Science and Technology. hlm. 1295-1305.

Wu, J., Shaun, J.G., Huiping, X. \& John, T.F. 2016. A practical method for predicting frequent use of emergency department care using routinely available electronic registration data. BMC Emergency Medicine 16(12): 1-9.

Yusoff, N.S.M., Liong, C.Y., Ismail, W.R., Noh, A.Y.M. \& Noor, N.A.M. 2017. Estimating the right allocation of resources on weekends and public holidays in Green Zone using hybrid methods. The 2017 UKM FST Postgraduate Colloqium: Proceedings of the University Kebangsaan Malaysia, Faculty of Science and Technology 2017 Postgraduate Colloqium. American Institute of Physics Inc. 1940: 020123.

Yusoff, N.S.M., Liong, C.Y., Ismail, W.R., Noh, A.Y.M. \& Ahmad, N. 2018a. A system dynamics model for predicting present and future demands in emergency department's Green Zone. Indian Journal of Public Health Research \& Development 9(11): 1566-1572.

Yusoff, N.S.M., Liong, C.Y., Noh, A.Y.M. \& Ismail, W.R. 2018 b. Discrete event simulation and data envelopment analysis models for selecting the best resource allocation alternative at an emergency department's Green Zone. Sains Malaysiana 47(11): 2917-2925.

Nazhatul Sahima Mohd Yusoff

Faculty of Computer Sciences \& Mathematics

Universiti Teknologi MARA (UiTM), Cawangan Kelantan

18500 Machang, Kelantan Darul Naim

Malaysia
Choong-Yeun Liong* \& Wan Rosmanira Ismail

Statistics Program

Faculty of Science and Technology

Universiti Kebangsaan Malaysia

43600 UKM Bangi, Selangor Darul Ehsan

Malaysia

Abu Yazid Md Noh

Emergency Department

Hospital Universiti Sains Malaysia (HUSM)

Jalan Raja Perempuan Zainab 2

16150 Kota Bharu, Kelantan Darul Naim

Malaysia

Norazura Ahmad

School of Quantitative Sciences

CAS Universiti Utara Malaysia

06010 Sintok, Kedah Darul Aman

Malaysia

*Pengarang untuk surat-menyurat; email: lg@ukm.edu.my

Diserahkan: 15 Mei 2018

Diterima: 8 Februari 2019 